\title{
The duty to take appropriate measures to prevent significant transboundary harm and private companies: insights from transboundary hydropower projects
}

\author{
Alistair Rieu-Clarke ${ }^{1}$
}

Accepted: 10 July 2020 / Published online: 23 September 2020

(c) The Author(s) 2020

\begin{abstract}
Recognition that hydropower plays a role in fostering sustainable development and helping countries move away from fossil fuels has led to a resurgence of planned projects on transboundary rivers around the world. Whilst these projects offer clear benefits, they are not without their socio-ecological impacts. An added feature of hydropower projects is that they tend to involve a wide range of actors that are responsible for their financing, planning, construction and operation (international and domestic; private and State). This begs the question, if it is ultimately the responsibility of States to ensure that these projects are in accordance with international law obligations, what does that responsibility entail when much of the activity is conducted by private companies? International law has a long tradition of placing States under an obligation to regulate the conduct of non-State activities so as to prevent transboundary harm. However, a closer review of the law relating to transboundary hydropower projects reveals that more could be done to guide States as to the appropriate measures that they might put in place to ensure that any hydropower projects involving private actors are implemented in an equitable and sustainable manner.
\end{abstract}

Keywords Hydropower · Transboundary harm · Human rights · Private companies · Due diligence
Abbreviations
EIA Environment Impact Assessments
ICJ International Court of Justice
ILC International Law Commission
SDGs Sustainable Development Goals
WWF Worldwide Fund for Nature

Alistair Rieu-Clarke

Alistair.rieu-clarke@northumbria.ac.uk

1 Law School, Northumbria University, Newcastle, UK 


\section{Introduction}

Hydropower is increasingly seen as an important contributor to several global targets and commitments, including the United Nations Sustainable Development Goals (SDGs) and the nationally determined contributions of the 2016 Paris Agreement. This has led to the rapid growth of the hydropower sector in recent years. A record-breaking 21.8 gigawatts (GW) of estimated hydropower capacity was put into operation in 2018 (International Hydropower Association 2019). Hydropower is seen as an important alternative to fossil fuels and a key contributor to mitigating the impacts of climate change and fostering sustainable development (Sustainable Energy 2019; cf. WWF \& The Nature Conservancy 2018). The potential to develop the hydropower sector further is therefore high. Whilst Africa is highlighted as the continent with the most untapped technical hydropower potential in the world, that potential is high in many other parts of the world (International Hydropower Association 2019). Hoes et al. (2017) estimate that hydropower has the potential to satisfy $33 \%$ of annually required energy, whilst hydropower production in 2017 was just $3 \%$.

Despite hydropower being seen as an important contributor to sustainable development, hydropower projects are not without their costs. These projects can lead to significant socio-ecological impacts, such as disrupting natural river flows, fragmenting river ecosystems, inhibiting migration paths and changing habitats, producing greenhouse gas emissions from reservoirs, and altering sedimentation flows (Simonov et al. 2019). In turn, such changes can have a major impact on the livelihoods of populations reliant upon the ecosystem goods and services provided by river systems.

Proponents of hydropower must therefore strike a balance between maximising the benefits of these projects, whilst mitigating any potential socio-ecological impacts. Striking such a balance is not easy. An additional complication is that many of these developments take place on rivers shared between countries. Whilst it has been proven, such as in the cases of the Columbia River (the USA and Canada) and the Senegal River (Senegal, Mali and Mauritania), that joint hydropower projects can offer a catalyst for cooperation between countries (Hensengerth et al. 2012); in other transboundary rivers, such as the Blue Nile (Egypt, Ethiopia and Sudan) and the Vakhsh River (Tajikistan and Uzbekistan), unilateral hydropower projects have rather been a source of tension between States (Yihdego et al. 2016; Menga and Mirumachi 2016).

A further complication of these large-scale hydropower projects is that they often involve not only States but private companies. These companies, often multinational in nature, play a range of roles related to the financing, planning, construction and operation of projects (see Merme et al. 2014). The involvement of both State and private companies poses a particular dilemma in terms of the applicable laws and standards that should apply (Tanzi 2014). Ultimately, it is the responsibility of States to ensure that these projects are in accordance with international law obligations, but what does that responsibility entail when much of the activity is conducted by private companies? This paper seeks to respond to this question by considering the normative requirements of the duty to take all appropriate measures to prevent significant transboundary harm. More specifically, the paper asks what measures might be appropriate for a State to adopt, in a scenario where much of the financing, planning, construction and operation of a hydropower project is carried out by private companies.

In order to better understand the basis of the normative requirement placed on States to prevent significant transboundary harm, the paper first traces the origins of the obligation 
and considers the scope of that obligation vis-à-vis both State and non-State actors. The paper then goes on to examine the extent to which the activities of private companies are considered in the law relating to international watercourses, and in particular the Convention on the Law of the Non-navigational Uses of International Watercourses (Watercourses Convention), and the Convention on the Protection and Use of Transboundary Watercourses and International Lakes (Water Convention). Having concluded that the analysis of the law relating to international watercourses only provides limited guidance, the paper explores whether any additional guidance can be found. Towards this endeavour, the paper asks whether three different avenues of enquiry might shed light on the 'appropriate' measures that should be adopted by States vis-à-vis private companies involved in hydropower projects, namely human rights instruments, the policies of international financial institutions and industry standards. The paper concludes by outlining the type of appropriate measures that both States and private companies might follow in relation to transboundary hydropower projects and identifies certain gaps within the existing framework in need of further consideration.

\section{Foundations of the obligation to prevent transboundary harm}

The obligation that a State prevent its territory from being used to cause harm to other States is well established in international law (Buchan 2016, p. 422). In the Corfu Channel case (ICJ 1949), the International Court of Justice (ICJ) stipulated that, as an obligation of customary international law, a State must not, 'allow knowingly its territory to be used for acts contrary to the rights of other States' [emphasis added]. Along similar lines, in the 1941 Trial Smelter case the arbitral tribunal famously stated that, "no State has the right to use or permit the use of its territory in such a manner as to cause injury by the emission of fumes in or transported to the territory of another or the properties or persons therein, when the case is of serious consequence and injury is established by clear and convincing evidence' [emphasis added] (United Nations 2006).

A critical feature in both these seminal cases is that they relate not only to the direct actions of a State, but also to the activities of others operating under the jurisdiction of that State. In the Corfu Channel case two British warships were struck by mines whilst passing through an international strait in Albanian waters. The ICJ subsequently determined that, whilst the Albanian government may not be directly responsible for the laying of the mines, they must have known about the existence of the mines, and they therefore had a legal duty to warn ships within the area of that threat. Similarly, the smelter in question in the Trail Smelter case was operated by the Consolidated Mining and Smelting Company. The tribunal maintained that the Canadian government had a responsibility to regulate the activities of such companies in order to prevent transboundary harm-in this instance by harmful emissions affecting forests and agricultural interests in the United States of America. This therefore begs the question, what would be the appropriate level of regulation that States might implement to prevent significant transboundary harm?

Ascertaining what might be the most appropriate level of regulation that a State should adopt rests on an understanding of the concept of due diligence. In the Alabama Case, a due diligence obligation was described as, 'such care as Governments ordinarily employ in their domestic concerns' (United Nations 2012). As observed by the International Law Commission (ILC), certain basic tenets of government should be in place, for instance, 'the Government concerned should possess, on a permanent basis, a legal system and material 
resources sufficient to ensure the fulfilment of its international obligations'; and 'the State must also establish and maintain an adequate administrative apparatus' (ILC 1999). However, what is 'reasonable' for one government may not be reasonable for another. As noted by the ILC (1956), due diligence can be said to be:

...due care in taking measures normally undertaken in the particular circumstances of the case, foreseeability of the injurious acts and the possibility of preventing their commission with the resources available in the State, necessary exercise of authority in apprehending the individuals who committed injurious acts and giving the alien the opportunity to bring a claim against such individuals [emphasis added]

Determining the requirements placed on States vis-à-vis private companies is therefore not an easy matter as it may vary depending on the circumstances of the case. However, are there still at least certain minimum normative requirements that can guide States when dealing with private companies involved in transboundary hydropower projects?

More generally, the 2001 ILC Draft Articles on Transboundary Harm from Hazardous Activities ${ }^{1}$ set out a series of 'appropriate measures' that all States should adopt in order to comply with their due diligence obligation to prevent significant harm. Article 5, for instance provides that, 'States concerned shall take the necessary legislative, administrative or other action including the establishment of suitable monitoring mechanisms' (ILC 2001). The ILC (2001) in its commentary to this Article addresses non-State actors by suggesting that, 'where activities are conducted by private persons or enterprises, the obligation of the State is limited to establishing the appropriate regulatory framework'. An important feature of this regulatory framework contained in Article 6 of the Draft Articles is that any activities likely to cause significant transboundary harm should be subject to prior authorisation of the State. However, the Draft Articles remain silent on the content of that regulatory framework, and even provides that, 'States are free to choose the form of such authorisation' (ILC 2001).

One feature of the regulatory framework that has attracted some discussion in international case law, is the requirement to assess potential impacts prior to any project authorisation. In the Pulp Mills Case, for example, the ICJ (2010) noted that pursuant to general international law, States are obliged to, 'undertake an environmental impact assessment where there is a risk that the proposed industrial activity may have a significant adverse impact in a transboundary context, in particular, on a shared resource' [emphasis added]. Whilst this passage supports the requirement that a State-and by implication any nonState actor planning a project-conduct an environmental impact assessment (EIA) where there may be a risk of significant adverse impact, the Court was keen to point out that general international law does not specify, 'the scope and content of an environmental impact assessment' (ICJ 2010). In the San Juan River Cases, the Court elaborated slightly on this obligation to conduct an EIA, by stating that,

... to fulfil its obligation to exercise due diligence in preventing significant transboundary environmental harm, a State must, before embarking on an activity having the potential adversely to affect the environment of another State, ascertain if there is a risk of significant transboundary harm, which would trigger the requirement to carry out an environmental impact assessment (ICJ 2015).

\footnotetext{
1 'Hazardous activities' are defined in the Draft Articles as, 'any activity which involves the risk of causing significant transboundary harm'.
} 
This passage from the Court's judgement would suggest the need for domestic procedures to be in place by which to trigger an assessment on whether any activity in a State's territory is likely to cause significant harm. However, the Court in reiterating its opinion in the Pulp Mills case, suggested that 'determination of the content of the environmental impact assessment should be made in light of the specific circumstances of each case' (International Court of Justice 2015). These cases, therefore, say little about the actual content or scope of any assessment, or the respective roles and responsibilities of a State vis-à-vis private companies. Additionally, with the exception of the Convention on Environmental Impact in a Transboundary Context (Espoo Convention) (see below) it is questionable whether there is a common practice for national EIA legislation to explicitly make reference to the transboundary nature of impacts, and considerable uncertainty under international law as to the appropriate scope of any impact assessment, i.e. does it cover both environmental and social impacts? Also, in terms of reach, should any private company engaged in such an exercise consider downstream water users even when those users are situated in another State? And, if so, how can a company engage with those users if there is no agreed platform between the States concerned, such as a transboundary river basin organisation?

\section{The treatment of private companies under the law of international watercourses}

Both the Water Convention and the Watercourses Convention provide a requirement that States adopt 'appropriate measures' to prevent significant transboundary harm. Unfortunately, these instruments also say little about the types of measures that might be considered appropriate in order to prevent significant harm that is a result of the activities of private companies involved in hydropower projects.

The most explicit recognition of the type of measures that might be considered 'appropriate' is provided within the Water Convention. Article 2 of the Water Convention calls upon Parties to adopt, 'relevant legal, administrative, financial and technical measures' to 'prevent, control and reduce transboundary impact'. More specific requirements are set out in Articles 2 and 3, although much of the focus is on establishing appropriate measures to address issues relating to water quality and transboundary pollution, e.g. prior licensing, monitoring and control of waste-water discharges, and adopting water-quality objectives and criteria (see generally (UNECE 2013); see also Article 21, Watercourses Convention).

Both instruments do provide additional guidance in relation to the planning phase of any transboundary hydropower project. Based on customary international law requirements the Watercourses Convention and the Water Convention require countries to notify and consult upon planned measures, to exchange relevant data and information, and to, in the words of the Water Convention, apply 'EIA and other means of assessment' (Art. 3(1)(h)). However, as noted above, there is little guidance on the scope of any EIA procedure, nor the requirements that any private company might follow.

Some guidance can be found in the Espoo Convention, which was adopted on 25 February 1991 and entered into force in 1997. There are currently 45 Parties to the Convention across Europe, Central Asia and the Caucasus. Pursuant to Article 2(1), parties are required to establish an EIA procedure that permits public participation. Such a procedure requires those planning an activity to submit 'environmental impact assessment documentation', to a 'component authority', which is defined in the Convention as, 'the national authority or 
authorities designated by a Party as reasonable for performing the tasks covered by this Convention and/or the authority or authorities entrusted by a Party with decision-making powers regarding a proposed activity' (Art. 1(ix)). Information to be included in the EIA documentation, includes a description of the proposed activity and its purpose, as well as any reasonable alternatives; a description of the environment likely to be significantly affected by the proposed activity or any alternatives; any mitigation measures envisaged to minimise likely impacts; gaps or uncertainties in knowledge; and any post-project monitoring plans (Annex II). In addition, the Party where the project is planned has the obligation to not only consult with any potentially affected Party, but also, 'ensure that the public of the affected Party in the areas likely to be affected be informed of, and be provided with possibilities for making comments or objectives on, the proposed activity' (Art. 3(8)). The Espoo Convention can therefore be seen as the most detailed multilateral convention covering both the scope and content of any transboundary EIA. However, with only 45 parties located in the pan-European region, the Convention can not be considered to be universally applicable. This begs the question, whether there are any other avenues of international law, that might provide further guidance on the types of measures that a State should adopt in relation to the conduct of private companies involved in transboundary hydropower projects. The following sections focus on three potential areas-human rights, the policies of international financial institutions and industry standards.

\section{Can a human rights perspective shed light on the duty to take all appropriate measures?}

In relation to human rights, the 1948 Universal Declaration of Human Rights provides an authoritative statement of customary international law in the field. This declaration is complemented by the 1966 International Covenant on Civil and Political Rights and the 1966 International Covenant on Economic, Social and Cultural Rights. Institutions, such as the UN Human Rights Council, and the UN Committee on Economic, Social and Cultural Rights have the responsibility to oversee the implementation and development of this Human Rights regime and have helped to further elaborate its content.

The closest link to transboundary water issues and human rights can be found in the 2002 General Comment No. 15 on the Right to Water by the UN Committee on Economic and Cultural Rights (GC15). GC15 aims to interpret a right to water from the more general right to a standard of living adequate for health and well-being, and the right to health contained in Articles 11 and 12 of the 1966 Covenant on Economic, Social and Cultural Rights. According to GC15, 'the human right to water entitles everyone to sufficient, safe, acceptable, physically accessible and affordable water for personal and domestic uses' (United Nations 2002).

No explicit reference to transboundary waters is made within GC15, although it does go slightly further than more general human rights instruments. For instance, States have an obligation to 'refrain from actions that interfere, directly or indirectly, with the enjoyment of the right to water in other countries' (United Nations 2002). In referencing the Watercourses Convention, this requirement can be seen as endorsing the obligation contained in Article 10 of the latter instrument, namely that 'special regard' should be given to 'the requirements of vital human needs', or the provision of 'sufficient water to sustain human life' (United Nations 1997). GC15 also makes a limited reference to non-State actors by suggesting that States are under a responsibility to, 'prevent third parties from interfering 
in any way with the enjoyment of the right to water' (United Nations 2002). However, whilst this might arguably place a State under a responsibility to safeguard the rights of citizens within another country-on the extraterritorial nature of the right to water, see McCaffrey (1992) and Bulto (2013) —it says little about the regulatory requirements that might be put in place to prevent companies from violating such rights.

In terms of the conduct of private companies and human rights, one of the most significant global initiatives is the Guiding Principles on Business and Human Rights adopted by the Human Rights Council, which have been described as, 'the authoritative global reference point for business' (United Nations 2011; Wettstein et al. 2019). The principles recognise a State's responsibility to take appropriate steps to prevent, investigate, punish and redress human rights abuses by private actors; and the responsibility of business enterprises to respect human rights. 'Business enterprises' are defined in the Guiding Principles as 'both transnational and others, regardless of their size, sector, location, ownership and structure (United Nations 2011). For States, the guiding principles stress that, whilst they have discretion over the specific measures adopted, effective policies, legislation, regulations and adjudication should be in place to protect human rights. These measures should extend to 'home States' taking appropriate steps, 'to prevent abuse abroad by business enterprises within their jurisdiction (United Nations 2011). The Guiding Principles also stress that business enterprises have a direct responsibility to protect human rights, through their own activities, as well as to prevent or mitigate human rights impacts that are directly linked to their operations, products or services. Although general in nature, the Guiding Principles go on to stipulate that business enterprises, 'should carry out human rights due diligence' (United Nations 2011); which may include ensuring that an assessment of human rights impacts is embedded in other processes such as environment and social impact assessments. Whilst not explicit, this requirement would suggest that companies carrying out hydropower projects on transboundary rivers, and those States regulating such conduct, consider the implications of those activities on the human rights of individuals and communities in countries potentially affected by the project, such as the requirement to safeguard sufficient water to sustain human life.

Further guidance is provided in General Comment 24 on State obligations under the International Context on Economic, Social and Cultural Rights in the context of business activities, which was adopted 10 August 2017 (GC24) (United Nations 2017). In many respects, GC24 builds upon the guiding principles. However, in relation to transboundary hydropower projects, a number of additional features are worthy of note. In terms of State obligations, the GC24 recognises a State's obligation to 'adopt legislative, administrative, educational and other appropriate measures, to ensure effective protection against Covenant rights violations linked to business activities and ensure that victims have effective remedies' (United Nations 2017, para. 14).

In terms of transboundary projects, such measures might suggest that victims from potentially affected States downstream of the planned activity, might have a right to access judicial or other procedures, or have a right to claim compensation or other relief in the State where such activities take place (see Article 32 of the Watercourses Convention). Closely aligned to this is the question whether there is a need for a global framework to harmonise minimum standards for civil liability within the context of transboundary harm. However, to date, any initiatives to develop such a global framework have been slow to get off the ground (see Boyle 2005; Dascalopoulou-Livada and Kolliopoulos 2017; Tanzi 2014).

In line with the International Labour Organisation Convention 169, GC24 also recognises the need for States to account for the impact of businesses activities on indigenous 
peoples, and 'in particular, actual or potential adverse impacts on indigenous peoples' rights to land, resources, territories, cultural heritage, traditional knowledge and culture' (United Nations 2017, para. 17). This suggests that private companies, under regulatory conditions of a State, must ensure that potential impacts of hydropower projects on indigenous peoples are considered beyond the sovereign borders of the State where the planned activity takes place.

Another important addition contained in GC24 relates to the exterritorial nature of the obligations under the Covenant. There is an explicit recognition in GC24 that, 'obligations of the Covenant are expressed without any restriction linked to territory or jurisdiction' (United Nations 2017, para. 27). Whilst this statement is primarily aimed at the conduct of corporations domiciled in their territory, causing human rights violations abroad, it would also appear to be relevant to the transboundary context. Moreover, GC24 reiterates the requirement under customary international law that prohibits a State from allowing its territory to be used to cause damage on the territory of another State, and that such prohibition extends to human rights law (United Nations 2017, p. 27).

\section{International financial institutions principles and procedures}

An important feature of many large hydropower projects, including transboundary hydropower projects, is project finance. In recent years, a number of policies, principles and procedures have been developed to guide both companies and States in ensuring that projects are developed with sufficient environmental and social safeguards in place. Whilst they are mostly voluntary in nature, this begs the question, whether these policies, principles and procedures may offer additional guidance in terms of what measures States might adopt to regulate the conduct of private companies involved in transboundary hydropower projects.

During the 1990s and early 2000, banks were often the target of high-profile NGO campaigns opposed to their financing of projects that had significant negative environmental and social impacts (Conteras et al. 2019, p. 307). As a result of pressure on the banking sector, a set of voluntary guidelines, the so-called Equator Principles, were adopted by eight banks in 2003. To date, 99 financial institutions in 37 countries have subsequently adopted the Equator Principles (see Equator Principles 2019)). The Equator Principles comprise ten key principles that address social and environmental risks related to largescale infrastructure projects. Essentially, these principles require financial institutions to not only assess the financial aspects of any project but conduct an environmental and social assessment. Transboundary aspects of a project are not directly addressed within the principles. However, through the carrying out of any assessment, it would be expected that transboundary considerations be taken into account. Another key requirement of the principles relates to stakeholder engagement, where financial institutions are required to, 'demonstrate that effective stakeholder engagement as an ongoing process in a structure and culturally appropriate manner with affected communities, and where relevant, other stakeholders' has been implemented (Equator Principles 2019). To foster implementation and compliance with the Equator Principles, a grievance mechanism, independent reviews, and ongoing monitoring and reporting have been established.

More recently, and in response to the adoption of the SDGs, UN Environment's Finance Initiative, which brings together over 200 financial institutions, has developed a set of Principles for Positive Impact Finance in 2017 designed to guide financiers and investors in making a positive impact on the environment and society (UNEP Finance Initiative 2019). 
Positive impact is defined in the principles as, 'that which serves to deliver a positive contribution to one or more of the three pillars of sustainable development (economic, environmental and social), once any potential negative impacts to any of the pillars have been duly identified and mitigated' (UNEP Finance Initiative 2019). The primary target audience for the principles is financiers, investors, donors and auditors. The principles emphasise the need for business activities to ensure that adequate processes, methodologies and tools are in place to identify and monitor impact, and that such impacts should be delivered in a transparent manner. These approaches should include consideration of environmental, social and corporate governance (ESG) criteria in investment valuations and assessments. Whilst not explicitly stated in the principles, this would suggest that companies account for any transboundary environmental and social impacts of a project. Additionally, the principles call upon companies to monitor the impacts of any projects in a transparent manner. Within a transboundary hydropower context, this suggests that any environmental and social impact assessments related to a planned project, or any continuous assessment of the impact of a project during its operation, be made available to all stakeholders.

In the interest of space, the analysis of development bank policies will concentrate on those of the World Bank, although similar policies tend to be in place for regional development banks. The World Bank has over 70 years of experience in financing projects on transboundary waters (Salman 2019). Early on, the Bank developed its own policies for determining whether to finance infrastructure projects on transboundary waters (Salman 2019; Paisley et al. 2017). The policy on international waterways (OP 7.5) encourages countries sharing transboundary waters to enter into agreements or arrangements for those waters subject to any proposed project and offers the assistance of the bank to support the negotiation of any agreements or arrangements (World Bank 2012). Additionally, the beneficiary State is obliged to notify all other riparians of the proposed project and provide the details thereof. Where, following notification, another riparian State objects to the proposed project, the Bank can appoint an independent expert to examine any objections.

More generally, the most recent policies of the World Bank are set out in its Environmental and Social Framework, which was approved in 2016 and applies to any new World Bank project as of 1st October 2018 (World Bank 2017). ${ }^{2}$ There are three key elements to the framework: a vision for sustainable development; the World Bank's environmental and social policy for investment project financing; and the environmental and social standards. The environmental and social policy outlines mandatory requirements for the Bank, whereas the environmental and social standards set out mandatory requirements for borrowers and projects. The standards cover issues related to the assessment and management of environmental and social risks and impacts; labour and working conditions; resource efficiency and pollution prevention and management; community health and safety; land acquisition, restrictions on land use and involuntary resettlement; biodiversity conservation and sustainable management of living natural resources; indigenous peoples/subsaharan African historically underserved traditional local communities; cultural heritage; financial intermediaries; and stakeholder engagement and information disclosure (World Bank 2017). Two critical features of the framework are the carrying out of an environmental and social assessment, 'to help ensure that projects are environmentally and socially sound and sustainable'; and that the borrower, with support by the Bank, conduct 'early and continuing engagement and meaningful consultation with stakeholders' (World Bank

\footnotetext{
${ }^{2}$ Existing projects approved earlier than 1st October 2018 will follow the previous safeguard policies.
} 
2017). The framework does not provide much detail on transboundary projects, although it does explicitly require that transboundary risks and impacts of any project be assessed. Additionally, where relevant, any environmental and social assessment, should account for the aforementioned operational policy for projects on international waterways (World Bank 2012).

Another important feature of the World Bank's Environmental and Social Framework is its grievance mechanism, which allows project-affected individuals and communities access to a project-specific grievance mechanism, the Bank's grievance redress service, and an independent fact-finding panel (the World Bank Inspection Panel). Each of these mechanisms is in place to monitor compliance with the Environmental and Social Framework.

\section{Guidelines and tools targeted at private companies}

The 2011 OECD Guidelines for Multinational Enterprises provide 'non-binding principles and standards for responsible business conduct in a global context consistent with applicable laws and internationally recognised standards' (OECD 2011). Although these guidelines do not address the specific context of transboundary impact, certain principles and measures suggest how businesses operating within a transboundary context might conduct themselves. Moreover, a number of cases dealing with the implementation of the guidelines have dealt with transboundary hydropower projects and the role of companies therein.

A specific chapter of the OECD guidelines is dedicated to human rights. Drawing upon the UN Guiding Principles, this chapter recognises that both States and enterprises have the responsibility to protect human rights. A key commitment of enterprises in this regard is to "carry out human rights due diligence as appropriate to their size, the nature and context of operations and the severity of the risks of adverse human rights impacts' (OECD 2011). Whilst the OECD guidelines do not, therefore, add much to the UN Guiding Principles in relation to human rights, they do go into more detail on matters related to sustainable development and the environment. Enterprises are accordingly obliged to, 'take due account of the need to protect the environment, public health and safety, and generally to conduct their activities in a manner contributing to the wider goal of sustainable development' (OECD 2011).

A key area of business activity encouraged by the OECD guidelines relates to riskbased due diligence. Companies are required to, 'identify, prevent and mitigate actual and potential adverse impacts' of their operations (OECD 2011). It could therefore be argued that there is an implicit requirement upon businesses to conduct risk-based due diligence of transboundary risks and impacts. As a complement to this due diligence requirement, the Guidelines recognise that stakeholder engagement, "can be particularly helpful in the planning and decision-making concerning projects or other activities involving, for example, the intensive use of land or water, which could significantly affect local communities' (OECD 2011). Enterprises are therefore encouraged to, 'engage in adequate and timely communication and consultation with the communities directly affected by the environmental, health and safety policies of the enterprise and by their implementation' (OECD 2011).

The importance of accounting for transboundary aspects of a project was evident in the case of the Pöyry Group and the Xayaburi Hydropower project in Laos, which was brought by 14 civil society organisations against Pöyry Group before the Finnish national contact 
point. ${ }^{3}$ Pöyry, a Finnish consulting firm, was hired by the Lao government to provide technical advice on the construction of the Xayabury dam (OECD Watch 2012). The Finnish national contact point confirmed that consulting companies such as Pöyry had a responsibility to conduct due diligence to avoid being linked to adverse transboundary social and environmental impacts caused by their clients.

The OECD guidelines also recognise that any due diligence requirement extends to, 'business partner entities in the supply chain and any other non-State or State entities directly linked to its business operations, products or services' (OECD 2011). The guidelines go on to state that, 'if the enterprise identifies a risk of contributing to an adverse impact, then it should take the necessary steps to cease or prevent its contribution and use its leverage to mitigate any remaining impacts to the greatest extent possible' (OECD 2011). The issue of linked business entities came up in the case of an Austrian company, Andritz Hydro Gmbh, which supplied hydropower-turbines for the aforementioned Xayaburi project (OECD 2014). What is perhaps most significant about the case from a transboundary context is the fact that Andritz Hydro GmbH was not responsible for the implementation of the project but merely the supply of a particular component, i.e. the turbines. However, it was clear that the OECD guidelines would still apply to the company's actions, and therefore require the company to consider the transboundary environmental and social impacts of a project as a whole before agreeing to supply the turbines (Finance \& Trade Watch 2018).

In relation to hydropower, the International Hydropower Association (IHA) has developed a set of sustainability tools, the development and implementation of which is overseen by the Hydropower Sustainability Council's governance committee. This committee is a multi-stakeholder group made up of energy companies, government agencies, financial institutions, and social and environmental NGOs. The IHA's 2018 Hydropower Sustainability Guidelines on Good International Industry Practice (HGIP), which build on the World Commission on Dams Recommendations (World Commission on Dams 2000), the Equator Principles, World Bank Safeguard Policies and IFC Performance standards, addresses four stages of a project's life cycle — early stage, preparation, implementation and operation. The HGIP is described as a 'normative document on how sustainability practice should be defined and measured in the hydropower sector' (International Hydropower Association 2018a). The guidelines cover six areas of good practice, including project assessment, management, stakeholder engagement, stakeholder support, compliance and outcomes. Although limited, the guidelines do make explicit reference to transboundary water issues.

At the assessment stage of a project, the importance of assessing the governance environment within which a project operation is highlighted, including, 'transboundary issues' (International Hydropower Association 2018a). Additionally, the guidelines highlight that specific external governance risks should be 'well-assessed' at the project preparation stage, including 'limitations or uncertainties in the institutional arrangements between neighbouring jurisdictions that address boundary-related issues, such as the management of project impacts in a river system, transport of goods and services, and information and resource sharing' (International Hydropower Association 2018a). Similarly, the guidelines emphasise that in the case of transboundary projects, it would be important to assess how a project fits with regional policies and plans, such as those developed by river basin

\footnotetext{
${ }^{3}$ National contact points, which are usually a government department, are established to monitor compliance with the OECD guidelines.
} 
organisations (International Hydropower Association 2018a). The guidelines also highlight the importance of assessing the environmental and social impacts of a project at a preparatory stage. This would, according to the guidelines, include, 'any transboundary aspects of the project' (International Hydropower Association 2018a); and would, 'allow for early and careful consideration of how transboundary issues will be addressed when assessing impacts, engaging with stakeholders, and defining mitigation measures' (International Hydropower Association 2018a).

In terms of management, the guidelines stress the importance of developing, 'management plans and processes for issues that affect project affected communities' (International Hydropower Association 2018a), and stipulate that these plans and process should include 'arrangements between jurisdictions that cover the implementation of plans, timing objectives, monitoring and evaluation mechanisms, and any handover arrangements' (International Hydropower Association 2018a).

In terms of the outcomes, the guidelines provide that during the preparation stage of project plans for downstream flows should take into account any transboundary objectives where relevant (International Hydropower Association 2018a). The Guidelines go on to explain that, 'transboundary objectives would be relevant if the downstream effects of the hydropower facility cross into a different jurisdiction than that in which the reservoir, dam and power station are found. If this is the case, then processes to assess and make determinations on downstream flow regimes should take into account transboundary stakeholder interests and objectives' (International Hydropower Association 2018a).

The Guidelines are supplemented by the 2018 Hydropower Sustainability Assessment Protocol (International Hydropower Association 2018b) and the Hydropower Sustainability Environmental, Social and Governance Gap Analysis Tool (HESG) (International Hydropower Association 2018c). In setting out a methodology for assessing a project throughout these key stages of its life cycle, the Protocol can be seen as a tool by which to implement the guidelines. The Protocol, therefore, highlights many of the same transboundary considerations, that are addressed in the guidelines. The protocol also calls for the identification of sources of data and information that can be used to assess the various aspects of a project. In the transboundary context, for instance, the protocol highlights examples of evidence for transboundary issues as including, 'records of meetings with representatives from governments, transboundary institutions and other key stakeholders'; and interviews with downstream authorities or community representatives (International Hydropower Association 2018b). Where gaps are identified through the Hydropower Sustainability Assessment Protocol, the HESG tool provides the basis for an action plan that can be used to address any shortcomings and ensure that a project is consistent with the sustainability guidelines (International Hydropower Association 2018c).

\section{Conclusion}

This paper asked what measures might be appropriate for a State to adopt as 'appropriate measures' to prevent significant transboundary harm in a scenario where much of the financing, planning, construction and operation of a hydropower project is largely carried out by private companies. In some respects, comfort might be gained from the fact that the activities of non-State actors have clearly been part and parcel of a State's obligation to prevent significant harm since the seminal cases in the $40 \mathrm{~s}$ and $50 \mathrm{~s}$, such as Trail Smelter and the Corfu Channel Case (ICJ 1949; UN 2006). States clearly have 
an obligation to ensure that an 'appropriate' legal and administrative framework is in place to mitigate against transboundary harm caused by private companies. However, significant gaps remain. In relation to the activities of private companies involved in transboundary hydropower projects, international law provides little guidance as to the scope and content of any national legal and administrative framework that might be deemed appropriate to regulate the conduct of private companies. The ILC would suggest that customary international law obliges States to adopt a regulatory framework and ensure that prior authorisation is in place for any project likely to cause transboundary harm (ILC 2001). Case law, including Pulp Mills and the San Juan River Cases, would suggest that a key component of any prior authorisation would be an assessment of any likely transboundary impacts. The need for such an assessment is also supported through an interpretation of both the Watercourses and the Water Convention. However, there is little guidance as to the scope and content of any transboundary assessment. Does, for instance, an EIA entail a State planning a hydropower project on a transboundary river simply account for any potential impacts that might occur within the territory other riparian States? Alternatively, would it require a joint EIA, whereby, all potential affected States, and possibly other potentially affected non-State actors, are engaged in the process? If a joint EIA was a requirement, how might a private company carry out such as assessment, when potentially affected communities live on the other side of a sovereign border. Arrangement of such an assessment might be particularly problematic when no cooperative arrangement or transboundary river basin organisation is in place. Whilst the ESPOO Convention offers some additional guidance, the majority of States involved in hydropower developments fall out with its jurisdiction.

A review of human rights laws leads to similar conclusions. Human rights are clearly applicable to water issues, including the transboundary context, and through instruments such as the Guiding Principles on Business and Human Rights and GC24, States are obliged to consider the activities of private companies vis-à-vis any potential human rights violations. However, the relevant instruments say little about the particularities of transboundary hydropower developments. States would appear to be obliged to put in place a regulatory system which ensures that private companies assess the human rights impacts of their operations, and in so doing consult with potentially affected communities, including the rights of indigenous groups. Additionally, it would appear that States should ensure that individuals potentially harmed by the actions of private companies have access to judicial redress. However, beyond that, the scope and content of any 'appropriate' regulatory framework are not easy to discern.

Some guidance might be found by looking at policies of international financial institutions, and business and sector-specific standards. However, it should be stressed that these policies and standards are not legally binding. States and the private companies that they collaborate with may choose not to sign up to such standards, or may find private financing elsewhere, which in turn leads to a greater risk that lower environmental and social standards being implemented. At best, such initiatives might therefore help to shape and interpret more general international law in this area. The World Bank policies on international waterways can be seen as important in this regard. What is evident, particularly from the review of the OECD Guidelines, is that private companies are increasingly confronted with the challenges in implementing hydropower projects on transboundary rivers; and responsible companies may well appreciate greater guidance on how they might implement projects on transboundary rivers.

In sum, further guidance to both States and private companies involved in transboundary hydropower projects is therefore desperately needed to ensure that these projects are 
implemented in an equitable and sustainable manner; and to ensure that the potential of hydropower in contributing to the SDGs and renewable energy needs is realised.

Open Access This article is licensed under a Creative Commons Attribution 4.0 International License, which permits use, sharing, adaptation, distribution and reproduction in any medium or format, as long as you give appropriate credit to the original author(s) and the source, provide a link to the Creative Commons licence, and indicate if changes were made. The images or other third party material in this article are included in the article's Creative Commons licence, unless indicated otherwise in a credit line to the material. If material is not included in the article's Creative Commons licence and your intended use is not permitted by statutory regulation or exceeds the permitted use, you will need to obtain permission directly from the copyright holder. To view a copy of this licence, visit http://creativecommons.org/licenses/by/4.0/.

\section{References}

Boyle, A. (2005). Globalising Environmental Liability: The interplay of national and international law. Journal of Environmental Law, 17(1), 3-26.

Buchan, R. J. (2016). Cyberspace, non-state actors and the obligation to prevent transboundary harm. Journal of Conflict \& Security Law, 21(3), 429-453.

Bulto, T. S. (2013). Extraterritoriality of the human right to water in international water law. Cambridge: Cambridge University Press.

Conteras, G., Bos, J. W. B., \& Kleimeier, S. (2019). Self-regulation in sustainable finance: The adoption of the Equator Principles. World Development. https://doi.org/10.1016/j.worlddev.2019.05.030.

Dascalopoulou-Livada, P., \& Kolliopoulos, A. (2017). The Kiev Civil Liability Protocol and the interaction between civil and administrative liability regimes. International Community Law Review. https://doi. org/10.1163/18719732-12341361.

Equator Principles, (2019). Equator Principles, November 2019, https://equator-principles.com/wp-content/ uploads/2019/11/The-Equator-Principles-November-2019.pdf.

Finance and Trade Watch (2018) Follow-up Statement. Concerning the specific instance complaint that Andritz Hydro $\mathrm{GmbH}$ contribute to human rights abuses and environmental damage in connection to the Xayaburi Hydropower Project in Lao PDR, http://www.ftwatch.at/wp-content/uploads/2018/10/ Follow-up_NGO-Statement_Andritz-OECD-Complaint-_03.Sept_.2018_Final.pdf. Accessed 29 November 2019.

Hensengerth, O., Dombrowsky, I., \& Scheumann, W. (2012). Benefit sharing in dam projects on shared rivers Retrieved November 29, 2019, from http://nrl.northumbria.ac.uk/6198/1/Benefit_sharing_on_share d_rivers.pdf.

Hoes, O. A. C., Meijer, L. J. J., van der Ent, R. G., \& van de Giesen, N. C. (2017). Systematic highresolution assessment of global hydropower potential. PLOS ONE. https://doi.org/10.1371/journ al.pone.0171844.

UNEP Finance Initiative, (2019). The Principles for Positive Impact Finance. A common framework to finance the Sustainable Development Goals, https://www.unepfi.org/wordpress/wp-content/uploa ds/2017/01/POSITIVE-IMPACT-PRINCIPLES-AW-WEB.pdf. Accessed 29 November 2019.

International Court of Justice, (1949). Corfu Channel Case. Judgement of April $9^{\text {th }} 1949$. ICJ Reports 1949, p. 4, https://www.icj-cij.org/files/case-related/1/001-19490409-JUD-01-00-EN.pdf. Accessed 29 November 2019.

International Court of Justice (2010) Pulp Mills on the River Uruguay (Argentina v. Uruguay). Judgement of April 20th 2010. ICJ Reports 2010, https://www.icj-cij.org/files/case-related/135/135-20100420-JUD01-00-EN.pdf. Accessed 29 November 2019.

International Court of Justice, (2015), Certain activities carried out by Nicaragua in the border area (Costa Rica v. Nicaragua) and Construction of a road in Costa Rica along the San Juan river (Nicaragua v. Costa Rica). Judgement December 16th 2015, https://www.icj-cij.org/files/case-related/150/150-20151 216-JUD-01-00-EN.pdf. Accessed 29 November 2019.

International Hydropower Association, (2018a). Hydropower sustainability guidelines on good international industry practice, https://www.hydropower.org/sites/default/files/publications-docs/hydropower_susta inability_guidelines_on_good_international_industry_practice.pdf Accessed 29 November 2019.

International Hydropower Association, (2018b). Hydropower sustainability assessment protocol, https:// www.hydropower.org/sites/default/files/publications-docs/hydropower_sustainability_assessment _protocol_-_july_2018.pdf Accessed 29 November 2019. 
International Hydropower Association, (2018c). Hydropower sustainability ESG tool, https://www.hydro power.org/sites/default/files/publications-docs/hydropower_sustainability_esg_gap_analysis_tool_-_ july_2018.pdf Accessed 29 November 2019.

International Hydropower Association (2019). 2019 hydropower status report-sector trends and insights, https://www.hydropower.org/sites/default/files/publications-docs/2019_hydropower_status_report_0. pdf. Accessed 29 November 2019.

International Law Commission, (1956). International responsibility. Report by F.V. García Amador, Special Rapporteur, https://legal.un.org/ilc/publications/yearbooks/english/ilc_1956_v2.pdf. Accessed 29 November 2019.

International Law Commission, (1999). Second report on international liability for injurious consequences arising out of acts not prohibited by international law (prevention of transboundary damage from hazardous activities). https://undocs.org/en/A/CN.4/501. Accessed 29 November 2019.

International Law Commission (2001) Draft articles on prevention on transboundary harm from hazardous activities, with commentaries. Report of the international law commission on the work of its fifty-third session, https://legal.un.org/ilc/texts/instruments/english/commentaries/9_7_2001.pdf. Accessed 29 November 2019.

McCaffrey, S. (1992). A Human right to water: domestic and international implications. Georgetown international environmental law review, 1-12.

Menga, F., \& Mirumachi, N. (2016). Fostering Tajik hydraulic development: examining the role of soft power in the case of the Rogun dam. Water Alternatives, 9(2), 373-388.

Merme, V., Ahlers, R., \& Gupta, J. (2014). Private equity, public affair: Hydropower financing in the Mekong Basin. Global Environmental Change. https://doi.org/10.1016/j.gloenvcha.2013.11.007.

OECD, (2011). OECD Guidelines for Multinational National Enterprises, OECD Publishing, http:// www.oecd.org/daf/inv/mne/48004323.pdf.

OECD, (2014). Andritz Hydro GmbH and Finance and Trade Watch Austria, https://mneguidelines. oecd.org/database/instances/at0005.htm. Accessed 29 November 2019.

Paisley, R., Denoon, R., Etmanski, T., \& Weiler, P. (2017). Transboundary waters, infrastructure development and public private partnerships. Brill Research Perspectives in International Water Law, 2(4), 1-75.

Salman, S. M. A. (2019). Notification concerning planned measures on shared watercourses - synergies between the watercourses convention and the World Bank policies and practice. Brill Research Perspectives in International Water Law, 4(2), 1-106.

Simonov, S. A., Nikitina, O. I., \& Egidarev, E. G. (2019). Freshwater ecosystems versus hydropower development: environmental assessments and conservation measures in the transboundary Amur river basin. Water. https://doi.org/10.3390/w11081570.

Tanzi, A. (2014). International law and foreign investment in hydroelectricity industry: A multidimensional analysis. In E. de Brabandere \& T. Gazzini (Eds.), Foreign Investment in the Energy Sector: balancing private and public I. The Hague: Brill.

United Nations, (1997). Convention on the Law of the Non-navigational Uses of International Watercourses. Report of the Sixth Committee convening as the Working Group as the Whole, https:// documents-dds-ny.un.org/doc/UNDOC/GEN/N97/097/94/PDF/N9709794.pdf?OpenElement. Accessed 29 November 2019.

United Nations, (2002). General Comment No. 15 (2002). The right to water (arts. 11 and 12 of the International Covenant on Economic, Social and Cultural Rights, https://www2.ohchr.org/english/ issues/water/docs/CESCR_GC_15.pdf. Accessed 29 November 2019.

United Nations, (2006). Trail smelter case. Reports of international arbitral awards, https://legal.un.org/ riaa/cases/vol_III/1905-1982.pdf. Accessed 29 November 2019.

United Nations, (2011). Guiding Principles on Business and Human Rights. Implementing the United Nations "Protect, Respect and Remedy" Framework, https://www.ohchr.org/documents/publicatio ns/GuidingprinciplesBusinesshr_eN.pdf. Accessed 29 November 2019.

United Nations, (2012). Alabama claims of the United States of America against Great Britain. Reports of international arbitral awards, https://legal.un.org/riaa/cases/vol_XXIX/125-134.pdf. Accessed 29 November 2019.

United Nations, (2017). General Comment No. 24 (2017) on State obligations under the International Covenant on Economic, Social and Cultural Rights in the context of business, https://tbinternet .ohchr.org/_layouts/15/treatybodyexternal/TBSearch.aspx?Lang=en\&TreatyID=9\&DocTy peID=11. Accessed 6 March 2020.

United Nations Economic Commission for Europe, (2013). Guide to implementing the Water Convention, https://www.unece.org/index.php?id=33657. Accessed 6 March 2020. 
OECD Watch, (2012). Siemenpuu et al vs Pöyry Group, https://complaints.oecdwatch.org/cases/Case_259. Accessed 29 November 2019.

Wettstein, F., Giuliani, E., Santangelo, G. D., \& Stahl, G. K. (2019). International business and human rights: a research agenda. Journal of World Business. https://doi.org/10.1016/j.jwb.2018.10.004.

World Bank, (2012). Operational Policy 7.50. Projects on International Waterways, http://web.worldbank. org/archive/website01541/WEB/0_C-137.HTM. Accessed 28 November 2019.

World Bank, (2017). Environmental and Social Framework. http://documents.worldbank.org/curated/ en/383011492423734099/pdf/114278-WP-REVISED-PUBLIC-Environmental-and-Social-Frame work.pdf. Accessed 29 November 2019.

World Commission on Dams, (2000). Dams and Development - a new framework for decision-making, https://www.internationalrivers.org/sites/default/files/attached-files/world_commission_on_dams_final _report.pdf. Accessed 28 November 2019.

WWF and the Nature Conservancy, (2018). Connected \& Flowing-A renewable future for rivers, climate and people, https://www.nature.org/content/dam/tnc/nature/en/documents/TNC_ConnectedFlowing_ Report_WebSpreads.pdf. Accessed 10 March 2020.

Yihdego, A., Rieu-Clarke, A., \& Cascão, A. (2016) How has the grand Ethiopian renaissance dam changed the legal, political, economic and scientific dynamics in the Nile basin? Water International, https:// doi.org/10.1080/02508060.2016.1209008. Accessed 10 March 2020.

Publisher's Note Springer Nature remains neutral with regard to jurisdictional claims in published maps and institutional affiliations. 